\title{
Новая визуальная жизнь шуточных вопросов \\ в интернет-мемах
}

\section{Пирет Воолайд}

Отделение фольклористики, Эстонский литературный музей, Эстония

piret@folklore.ee

\begin{abstract}
Аннотация: Исследование посвящено эстонским шуточным вопросам (с подвохом) в интернет-мемах - вербальным диалоговым шуткам, представленным визуально. В работе рассматривается визуализация и распространение в Интернете шуточных вопросов, относившихся ранее к устной (и только вербальной) традиции, с добавлением иллюстраций. В большинстве случаев визуальный ряд не означает появление новых семантических уровней (образность шуточного вопроса проявляется скорее на вербальном, вопросноответном уровне), однако иллюстрации свидетельствуют о желании соотнести ранний жанр с современными средствами выражения. Анализ осуществляется с целью ответить на следующие вопросы: Какие шуточные вопросы иллюстрируются, и какие приёмы используются для этого наиболее часто? - Насколько часто и каким образом мотивацией служат шуточные вопросы доциорового периода? - Что визуализация придаёт жанру шуточных вопросов, бытовавших ранее только в вербальной форме, в эстетическом и эмоциональном плане с точки зрения передачи сообщения?
\end{abstract}

Ключевые слова: мемы, новостной фольклор, шуточные вопросы, загадки, юмор 
Шуточные вопросы - наиболее жизнеспособный поджанр загадок. Это - вопросы-загадки, имеющие целью ввести адресата в заблуждение и вызвать смех. Они имеют фриксированную форму, начинаясь с вопросов: Почему...?, Что такое...?, Что будет, если...?, В чёл разнииа лежду...?

В эстонском материале к таковым относится серия анекдотов об Армянском радио - одном из главных явлений советских анекдотов, особенно в 1960-70-е годы. Как правило, анекдоты из этой серии начинаются словами Вопрос Арлянсколу радио или Арлянское радио спрашивают..., после чего следует весьма обыденный вопрос, на который даётся парадоксальный или даже абсурдный ответ с изрядной долей сатиры на «реалии советской жизни».

Динамика использования жанра в социальных сетях демонстрирует тенденцию к иллюстрированию и визуализации текстов. Характерной особенностью этих мультимодальных и мультимедийных меметических репрезентаций является их литературное, цифровое, визуальное качество. А бытовавшая до этого устная или письменная, но всё ещё вербальная загадка входит в диалог с визуальностью.

Далее будет представлен обзор новой жизни шуточных вопросов в Интернете и предпринята попытка ответить на следующие вопросы:

- Какие загадки иллюстрируются? Каким образом?

- Как часто вдохновением служит доцифровой период? Как это выражается?

- Что визуализация даёт традиционно вербальным шуточным вопросам в эстетическом и эмоциональном плане (является ли изображение просто иллюстрацией к тексту, или же вербальное и визуальное образуют новое целое)?

\section{Краткий обзор эстонского архива загадок}

Загадки характеризуются диалоговой игрой и обязательной структурой «вопрос-ответ». Такая структура является определяющим элементом данного поджанра загадок. И если традиционные загадки содержат описание и ответ, то современные шуточные вопросы состоят из прямого вопроса и ответа. 
Новая визуальная жизнь шуточных вопросов в интернет-мемах 399

Корпус загадок в Эстонском фольклорном архиве, насчитывающий 177000 текстов, может быть разделён на две части:

1. около 130000 ранних традиционных загадок составляют основную часть корпуса: Üks hani, neli nina? - Padi. (Один гусь, четыре клюва? - Подушка.);

2. 47000 текстов представляют собой новые формы загадок, среди которых к наиболее популярным подвидам относятся:

а. шуточные вопросы (с подвохом) (около 25000 записей): Как можно догадаться, что под кроватью находится слон? - Кровать находится под потолкол;

b. игра слов, или каламбуры (около 5000 записей): Когда человек бывает деревол? - Когда он со сна;

c. акронимы (около 3000 записей): СССР? - Слерть Сталина спасёт Россию;

d. ребусы (около 7500 записей): на рисунке? - Медведь карабкается на дерево.

Корпус эстонских загадок в полном объёме имеется в открытом доступе в Интернете (см. Voolaid 2002; Voolaid 2003; Voolaid 2004a; Voolaid 2004b; Krikmann \& Krikmann 2012).

Далее речь пойдёт о шуточных вопросах (с подвохом) и новых формах развития этого поджанра загадок в Интернете.

\section{Некоторые теоретические подходы}

Исследователи придерживаются единодушного мнения о том, что юмор и шутка являются культурными универсалиями человеческого поведения (см. Raskin 1985; Davies 1998; Oring 2003 и мн. др.). В плане содержания и тематики, а также с точки зрения техник конструирования все нынешние малые жанры фольклора, имеющие вопросно-ответную структуру, чаще всего остроумную. Поэтому их можно рассматривать и интерпретировать также в рамках общей теории юмора.

Сальваторе Аттардо и Виктор Раскин, считая загадку формой юмора, рассматривают её с точки зрения глобальной теории вербального юмора (GTVH) (Attardo \& Raskin 1991: 297 ff). Они выделяют шесть главных уровней выражения словесного юмора, 
каждый из которых соответствует определённому ресурсу знаний: 1) язык, 2) стратегия повествования, 3) цель, 4) ситуация, 5) логический механизм, 6) оппозиция семантических сценариев. Жанр или поджанр текста в значительной степени определяются стратегией повествования (Attardo \& Raskin 1991: 300). А поскольку шутки с кульминационным пунктом соответствуют форме короткого рассказа (анекдота) или шуточного вопроса, то, по сути, выбор лежит между этими двумя жанрами. Но иллюстрирование текстов вводит новые плоскости, которые также следует принимать во внимание. За вопросом следует юмористический ответ, но что делать с визуальной стороной? Чем она мотивирована?

Исследователи юмора называют шуточные вопросы также диалоговыми анекдотами. В эстонской традиции лучшим известным примером таковых может служить серия вопросов Армянскому радио, а также другие шутки с вопросно-ответной структурой. Кроме этого, используется термин псевдозагадка, обозначающий ситуацию, когда загадка вроде как загадывается, но ответ на неё не ожидается, а спрашивающий, выдержав небольшую паузу, сам даёт на неё ответ. Делия Кьяро (Chiaro 1992: 69) называет подобные загадки квазизагадкали.

Шуточные вопросы могут использоваться как загадки. Концовки текстов в них одни и те же, что означает, что жанр определяется текстовой и/или коммуникативной «поверхностной структурой» вокруг «основного ядра» (вопрос-ответ). Это может быть повествовательный монолог с юмористической целью (анекдот):

- Учительвшколеспрашивает: Когоможноназватьцарёмзверей?»

- Юку: «Директора зоопарка». < Йыхви, 1992.

Также это может быть диалог с тем же содержанием, но без называния его участников (в нашем примере - шуточный вопрос):

Кто является царём зверей? - Директор зоопарка. < Кейла, 1992.

Зачастую вопросно-ответная структура диалога включает более или менее активное участие слушателя в исполняемой ситуации. Российские исследователи юмора Елена Шмелёва и Алексей Шмелёв также указывают на схожесть шуточного вопроса со структурой загадок: спрашивающий как бы задаёт слушателю загадку, но не ожидает ответа и часто даже не выдерживает паузы, прежде чем самому дать неожиданный и остроумный ответ (Шмелёв \& Шмелёва 2002: 97-98). 


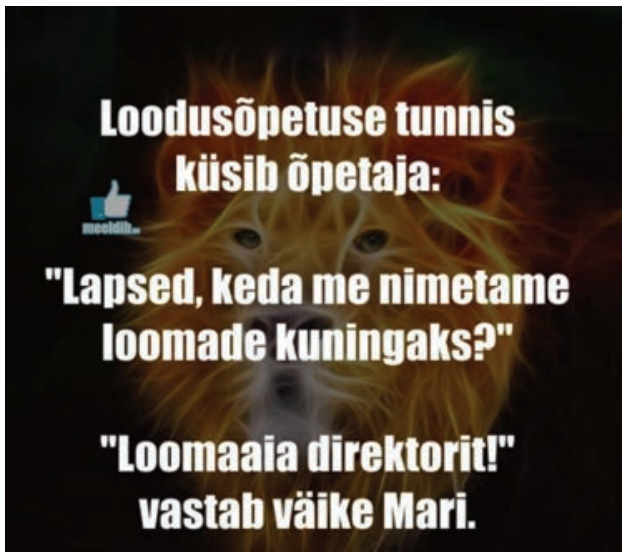

Рис. 1. Диалоговый анекдот на базе шуточного вопроса, представленный в виде мема: На уроке природоведения учитель спрашивает: "Дети, кого мы называем иарём зверей?" "Директора зоопарка!" - отвечает маленькая Мари. (meeldib.eе).

В случае визуализации ранних шуточных вопросов в Интернете (мемы) пердормативная ситуация не предполагает наличие рассказчика и слушателя в классическом понимании. Вместо этого имеется автор и аудитория/адресат. Внимание адресата привлекается вопросом, однако всё в целом ему представлено одновременно - вопрос, ответ и иллюстрация.

\section{Меметическое целое в диалоге вербального} и визуального

В контексте настоящей работы внимание фокусируется на мемах как центральном элементе цифровой культуры. Лимор Шифман определяет их как «группу цифровых элементов, имеющих общие характеристики контента, формы и/или позиций». Исследователь описывает мемы не только как текст, но и как нечто практическое: мемы «создаются с осведомлённостью друг о друге и распространяются, копируются и/или преобразовываются множеством интернет-пользователей» (Shifman 2013). 
В Эстонии данная тема рассматривалась Аннели Баран (Baran 2013), изучавшей важность визуализации в понимании образной речи на примере демотиваторов и рекламных объявлений. Она пришла к выводу, что визуализация связана не с дословным, а, скорее, с образным содержанием высказывания.

Но где же происходит диалог буквального и образного в шуточных вопросах? Мемы являются визуализированными текстами, содержащими шуточные вопросы и изображения и реализуемые и понимаемые как одно целое (текст и изображение). Текст и изображение неотделимы друг от друга без потери значения, хотя формально их можно разделить. Визуальная информация - важная составляющая мема, что особенно касается его составного значения и интерпретации. Визуализированный шуточный вопрос - одно из явлений, где «вербальный язык и графические изображения не имеют явственных различий в плане практического коммуникативного использования, наоборот, они пересекаются и зачастую взаимозависимы с точки зрения оптимального функционирования» (Laaniste 2005: 617).

\section{Материал и анализ}

Исходный материал для анализа был загружен в 2016 году с популярного эстонского сайта развлечений www.meeldib.ee ('нравится'), принадлежащего крупнейшей эстонской ежедневной газете «Postimees». Сайт открыт для всех зарегистрированных пользователей, желающих запостить шутки, фотографии, видео, при этом сообщения должны быть «интеллектуальным творением самих авторов». Для фольклориста это - анонимные сведения. Среди постов трудно различить совершенно новое творчество, вариации или повторное использование.

Всего постов насчитывается около 8 000, из них 5 \% (400) являются классическими шуточными вопросами. Исследуемые в статье мемы хранятся в цифровом виде в научном архиве EFITA (EFITA.FO2.008) отделения фольклористики Эстонского литературного музея. Сравнительные данные представлены в базе данных «Эстонские шуточные вопросы» (www.folklore.ee/ Keerdkys, Voolaid 2004a). База содержит шуточные вопросы, хранящиеся в Эстонском фольклорном архиве. 
Новая визуальная жизнь шуточных вопросов в интернет-мемах 403

Шуточные вопросы касаются широкого спектра тем. $\mathrm{K}$ наиболее крупным тематическим категориям, которые находят отражение в шуточных вопросах, относятся:

1. Шуточные вопросы как реакция на реальные (например, политические) события; новостной фольклор (ньюслор) с настоящими политиками в качестве персонажей;

2. Шуточные вопросы об отношениях мужчин и женщин, в т. ч. гендерные стереотипы;

3. Другие повседневные темы, например алкоголь и употребление спиртного, IT-технологии, потребительская культура.

Теоретически эти категории могут накладываться друг на друга, например, бытовое употребление алкоголя и взаимоотношения полов могут быть одновременно представлены в новостном фольклоре, возникшем после какого-либо конкретного события. Тем не менее, в зависимости от точки зрения и акцентирования, эти категории можно выделить в качестве трёх основных. Во всех тематических категориях наблюдается тенденция к иллюстрированию старых советских шуток.

1. В первую очередь рассмотрим мемы в качестве новостного фольклора (ньюслор). Согласно определению Рассела Франка, новостной фольклор - это фольклор, обусловленный медиа-сообщениями о повседневных событиях и дающий на них комментарии (Frank 2011). Он может находить выражение во многих формах фольклора, таких как шутки, городские легенды, фотожаба, иронические трактовки новостей, неофициальные циркуляры, пародии на песни и стихи, фольклор на основе коммерческой и политической рекламы, комиксы и анимация. Появление шуточных вопросов также может быть мотивировано реальными событиями, в первую очередь скандальными или трагичными. С одной стороны, загадки видятся отражением действительности, но чаще - это представление, созданное современными медиа. По диалоговой форме и краткости этот жанр может быть описан как эфемерный оперативный юмор.

Форма шуточных вопросов настолько кратка, что зачастую понимание шутки требует хорошего знания социокультурного контекста. База данных эстонских шуточных вопросов содержит 


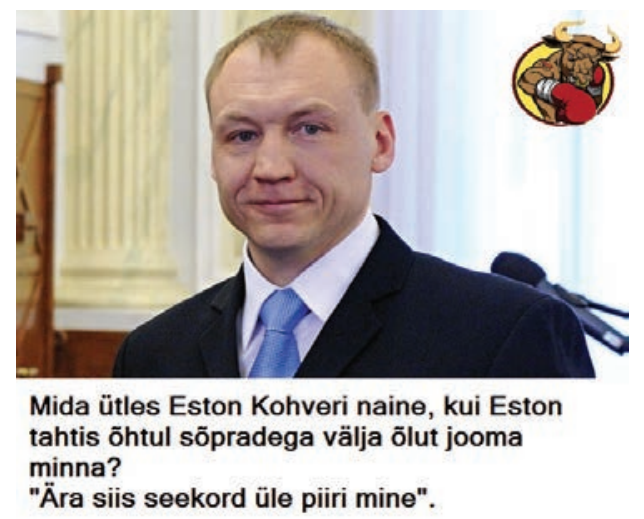

Рис. 2. Что сказала жена Эстона Кохвера, когда тот собрался на вечеринку с друзьяли? - На этот раз не переходи гранииу! (https://www.facebook.com/709610179107346/photos/a.7098279657 $52234.1073741828 .709610179107346 / 859094794158883 /$ ?type $=3 \& \mathrm{t}$ heater (дата обращения 29.09.2015)).

множество текстов, получивших широкое распространение после определённых событий, при этом отсутствует дополнительная информация об этих событиях, поскольку предполагается, что аудитория знает контекст.

Так, в шутке про Эстона Кохвера важно знать, что он офицер Службы внутренней безопасности Эстонии, задержанный ФСБ (Федеральная службба безопасности) России 5 сентября 2014 года при сомнительных обстоятельствах, что стало причиной существенного охлаждения в эстонско-российских политических отношениях. В России Э. Кохвер был осуждён за шпионаж и приговорён к 15 годам тюремного заключения, но в сентябре 2015 года был возвращён в Эстонию в рамках обмена заключёнными. Шутка про Э. Кохвера распространилась в Эстонии только после его освобождения. Очевидно, что до этого вопрос был слишком щекотливым, чтобы шутить на эту тему.

Образность и двусмысленность уже прописаны в вербальной части шутки и нет необходимости подчёркивать это ещё раз посредством визуальных элементов. Поэтому на иллюстрации отсутствует двусмысленность, она однозначна. 


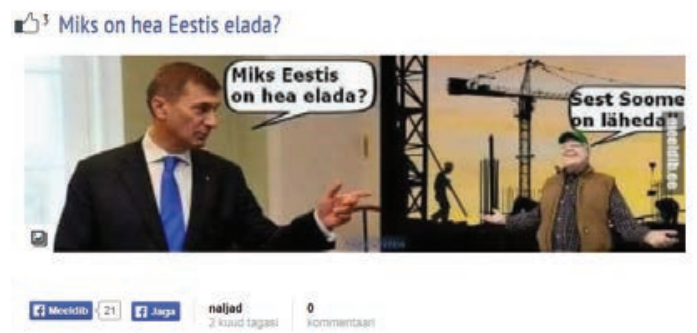

Рис. 3. Почему в Эстонии хорошо жить? - Потому что Финляндия близко. (meeldib.ee).

В данном комиксе бывший премьер-министр Эстонии Андрус Ансип задаёт вопрос строителю, работающему в Финляндии. Шутка указывает на соседнюю Финляндию как на основную страну выезда эстонцев в условиях открытого рынка рабочей силы в Европейском Союзе.

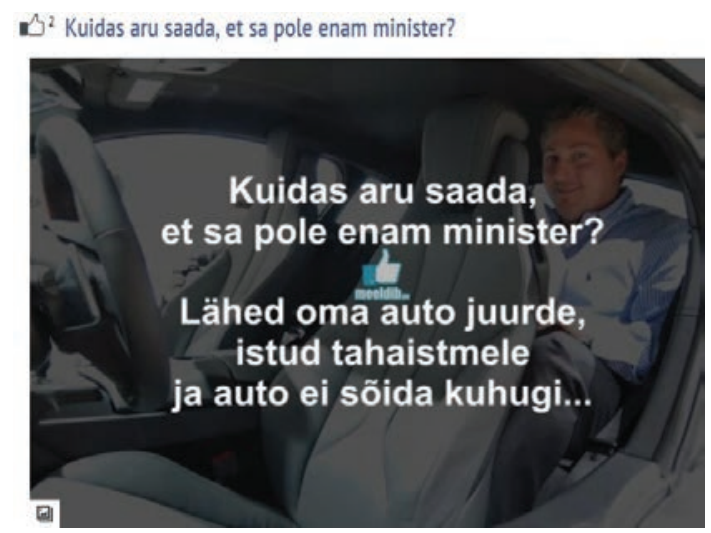

Рис. 4. Как понять, что ты больще не министр? - Тьь идёшь к своему автомобилю, садишься на заднее сиденье, но автомобиль не трогается... (meeldib.ee). 
Зачастую целью шуточных вопросов являются политики. Примечательно, что популярные в советское время текстовые шутки сегодня очень часто встречаются в виде визуальных мемов в сети.

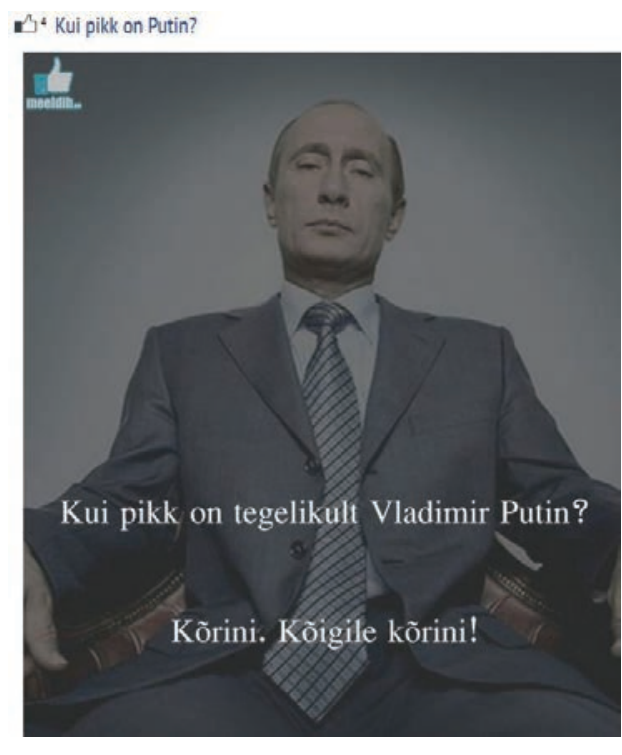

Рис. 5. Какой на самол деле рост у Владимира Путина? - По горло. Всем по горло! (meeldib.ee).

К таковым относятся тексты, используемые в контексте современной политики, будь то цитаты или целые шутки. В качестве примера можно назвать шутку о Путине: Какой на салол деле рост у Владилира Путина? - По горло. Всел по горло! (рис. 5). По архивным данным, в этой шутке часто фригурируют и другие персонажи, такие как Ленин, Брежнев или Хрущёв: Какой рост у Хрущёва? - В сантилетрах не знаю, но нал он по горло (= мы сыты им по горло).

Ярким примером новой жизни советской шутки уже в виде шуточного вопроса служит также следующий текст: Назовите три великих победы (победа - võit) Советского Союза. - Плоховато (kehvavõitu), маловато (vähevõitu), дороговато (kallivõitu) (записано в 1985 г. в Вяндра, RKM I 21, 335 (35)). Когда речь 
идёт о плохой жизни или бестолковости руководящих политиков, Советский Союз легко заменяется Европейским Союзом. Шаблонные параллели между устройством жизни в Советском Союзе и Европейском Союзе в народе проводятся нередко (см. также Laineste \& Voolaid 2016: 30). В следующем примере (рис. 6) в шуточном вопросе фригурируют эстонский политик и автор фильмов Марк Соосаар, известная в Эстонии песенница Кихну Вирве в традиционной народной одежде и политик Имре Сооээр.

\section{๑" Millised on Eesti Vabariigi kolm suurt vōitu?}

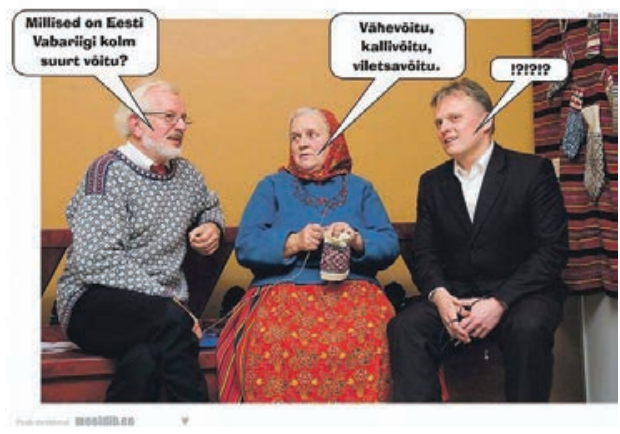

Рис. 6. Каковы три великих победы (võitu) Эстонской Республики? - Маловато (vähevõitu), дороговато (kallivõitu), плоховато (viletsavõitu). (meeldib.ee).

Отсюда явствует, что люди очень хорошо помнят советские шутки, и это интересно. Шутки широко бытовали в устной традиции, и поэтому сегодня легко проводятся параллели между советской жизнью и жизнью современных эстонцев. Часто можно наблюдать отнесение шуточных вопросов советского времени к современным эстонским политикам, что может указывать на то, что народ видит определённые параллели в общественном устройстве в прошлом и сегодня.

2. Шуточные вопросы о мужчинах и женщинах и их взаимоотношениях, относящиеся ко второй тематической категории, соответствуют известным стереотипам, например, женщины 
в них представлены как сексуальные объекты (в рекламе и пр.). В эту же категорию входят шутки о блондинках из 1990-х. К примеру, мужчины и женщины представлены на иллюстрациях следующим образом.

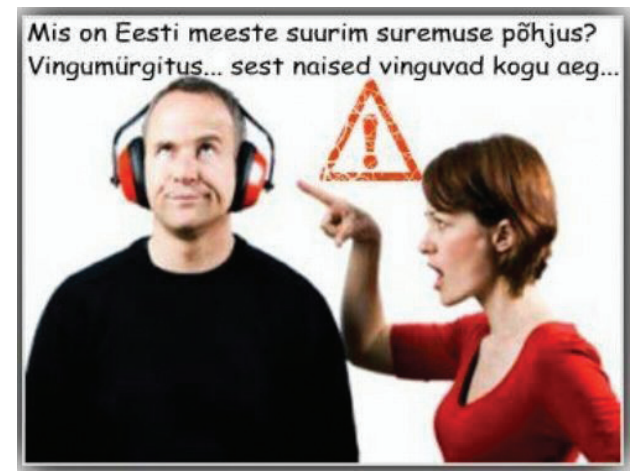

Рис. 7. Какая наиболее частая причина смерти эстонских мужчин? - Отравление угарныл газом... потому что женщинь всё время ноют... (ср. угар - ving и ныть - vinguта) (meeldib.ee).

$B^{2} \quad$ Milline on ideaalne abielumees?
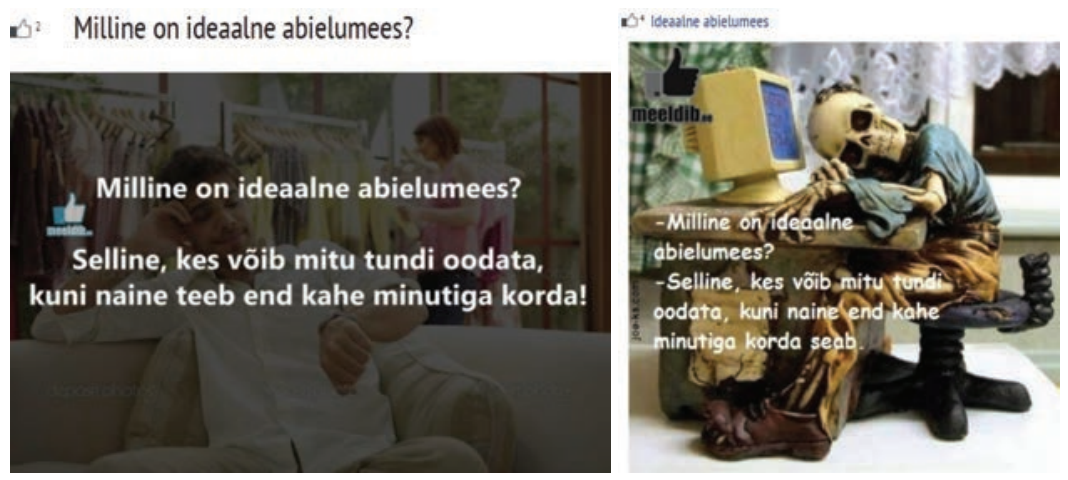

Рис. 8. Один и тот же вопрос нередко визуализируется по-разному. Какого мужчину можно назвать идеальныли супругол? - Такого, который может несколько часов прождать, когда жена за две минуты приведёт себя в порядок. (meeldib.ee). 
Новая визуальная жизнь шуточных вопросов в интернет-мемах 409

Имеется множество буквальных иллюстраций. $К$ примеру, если в вопросе упоминается автомобиль, то и на иллюстрации изображён автомобиль, если алкоголь, то присутствуют бутылки и стаканы.

Шутки о блондинках (обыгрывающие глупость) встречаются часто, при этом интересно то, что на иллюстрациях к ним изображаются не сами блондинки, а любые другие упомянутые в шутке объекты. И это, скорее, уникальные экземпляры, а не повторы.
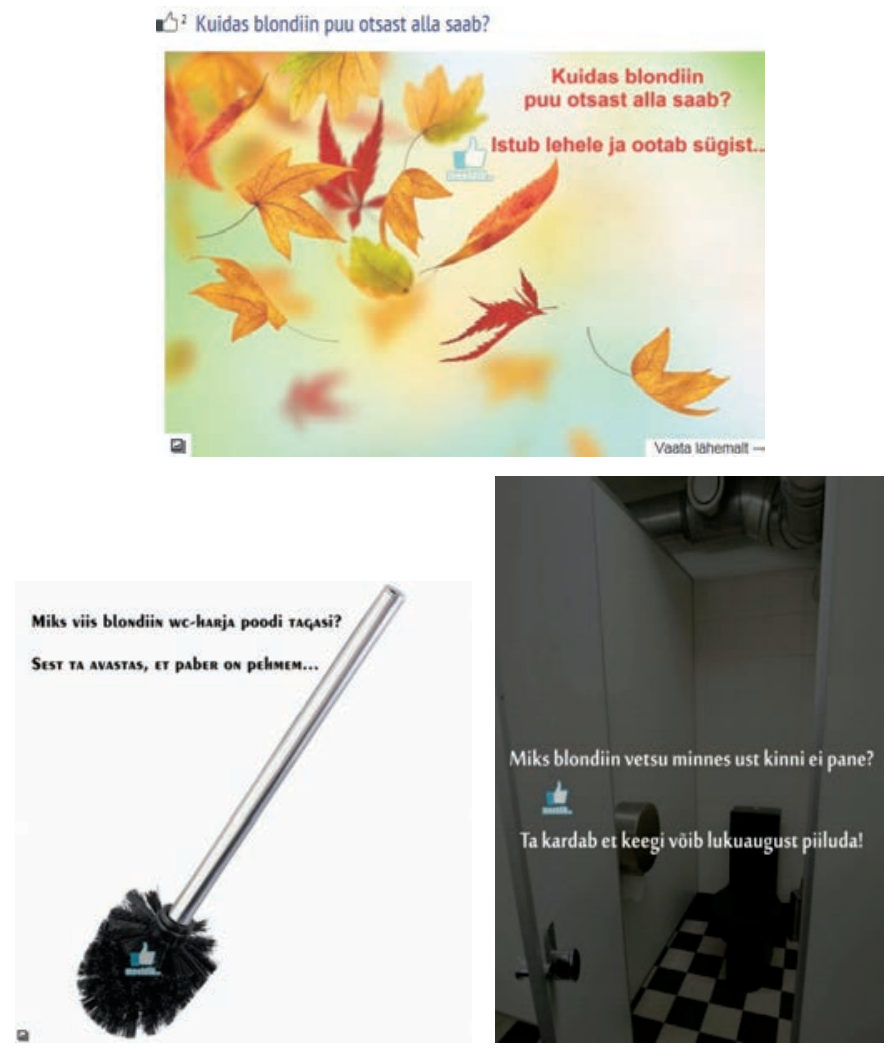

Рис. 9. Блондинка сидит на дереве. Как она спустится? - Сядет на листик истанет ждатьосени; Почему блондинкавернула туалетный ёршик обратно в магазин? - Потому что поняла, что бумага мягче; Почему блондинка, идя в туалет, не закрывает дверь?-Она опасается, что кто-то может подалядеть в замочную скважину. (meeldib.eе). 
Шутки о блондинках были широко распространены в 1990-е годы, но в Эстонии они оказались очень популярны также, например, в материалах по школьному фольклору, собранных в 2007 году (как и шутки про слона).

Согласно утверждению немецкого фольклориста Сабины Винкер-Пьефо, шутки о блондинках пропагандируют непревзойдённую женскую глупость, словно ум - это врождённая привилегия только мужчин. Индивидуальный пол находит выражение в культуре и обществе, и это клише можно расположить в один ряд с более ранними стереотипами, такими как своенравная жена с толкушкой в руке, злая тёща, секс-бомба с низким уровнем IQ, секретарша-нимфоманка (Wienker-Piepho 1999: 135). В мужском репертуаре юмора образ блондинки мог бы распространиться на всех женщин, если бы не было шуточных вопросов, нацеленных на мужчин: Почелу шутки о блондинках такие короткие? - Чтобь и мужчинь могли ux понять (Virtanen 2000: 5); Как узнать мачо? - Когда вода поднилется до пупка, он скажет: «Это улу непостижило! (буквально 'выше ума')» $\mathrm{EFA,} \mathrm{KP} \mathrm{33,} 134$ (2.F).

В шутках, высмеивающих скудоумие блондинок, может выражаться протест против идеала красоты, недоступного простому человеку. С другой стороны, по мнению многих исследователей, на появление подобных шуток сильное влияние оказали социокультурные процессы в обществе (осознание женского вопроса, изменение положения и повышение значимости женщин в обществе, концентрация внимания на проблематике равноправия полов во второй половине 1990-х гг. См. также Oring 2003; Stanoev 2010).

Иногда вопросы о блондинках связаны с этническими объектами (а порой и с рядом других) и могут объединяться в своего рода серии (см. также Raskin 1985: 185-189). Для создания шутки о блондинке зачастую достаточно заменить в вопросе другой персонаж, соответствующий глупому образу (чукча, советский милиционер т.д.), блондинкой: Почему блондинка не ест варенье? - Голова не пролазит в банку.

В эстонском языке блондин/блондинка вошли в оборот в качестве синонимов к слову глупый, и в этом случае светлый цвет волос стал совершенно неважным. Блондинка может демонстрировать свою недалёкость во всевозможных жизненных ситуациях. Одной из наиболее подходящих областей для этого 
Новая визуальная жизнь шуточных вопросов в интернет-мемах 411

служат современные технологии, что кажется действительно выше её сил. В широком смысле, здесь также может выражаться страх рядового человека перед сложной техникой.

3. Третью тематическую категорию образуют всевозможные бытовые темы. К наиболее популярным относятся, например, компьютер и технологии. В шутках этой категории также просматривается тенденция оснащать тексты иллюстрациями, однако изображения не всегда поддерживают образную составляющую шуточных вопросов.

\section{b: Mida teevad arvutifännid?}
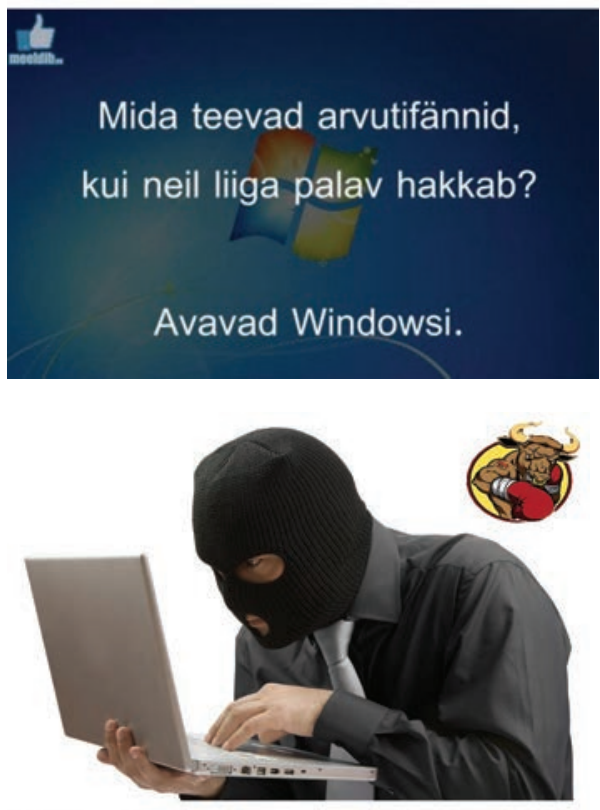

Milline on hea naaber?

See, kes ei pane oma wifit parooli alla.

Рис. 10. Среди визуализированного материала в отдельную подкатегорию выделяются шуточные вопросы эпохи компьютеров. Что делают любители колпьютеров, когда ил становитсяжарко?-Открьвают Windows (meeldib. ее); Какого соседа можно считать хорошил? - Такого, который не ставит парольнасвой Wifi (https://www.facebook.com/709610179107346/photos/a.70982 7965752234.1073741828.709610179107346/756846664383697/?type=3\&theater). 
В качестве часто используемой темы, актуальной во все времена, к данной тематической категории относится потребление алкоголя (например, рис. 11).

B. Mida teeb kapten, kui laev upub?

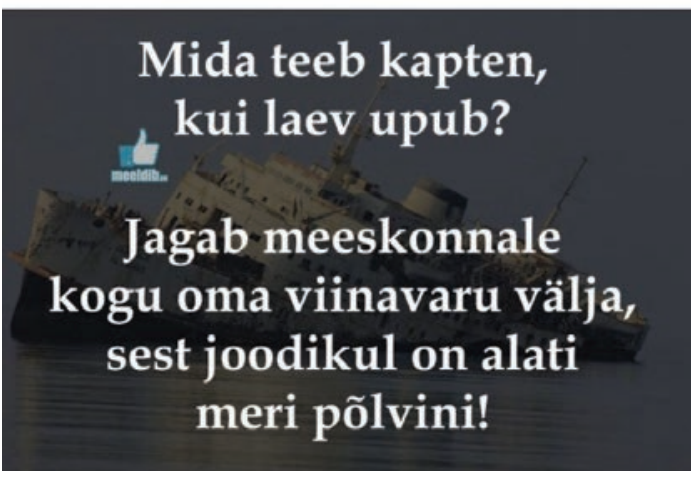

Рис. 11. Что делает капитан, когда корабль тонет? - Раздаёт команде все запасы алкоголя, потому что пьяному всегда море по колено! (meeldib.ee).

В редких случаях шуточный вопрос бывает о конкретном изображении. Обычно иллюстрации с вопросом напрямую не связаны. В следующем примере (рис. 12) вопрос касается боксёра на фотографии:

B Nii suured kontakläätsed

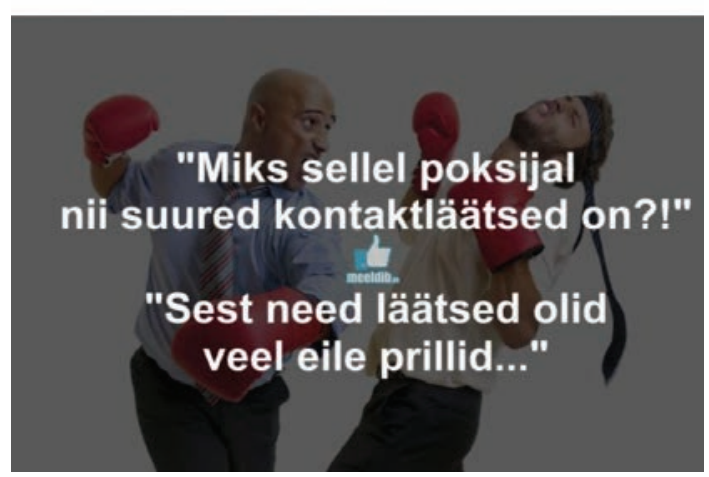

Рис. 12. Почелу у этого боксёра такие большие линзь?! - Потолу что эти линзы ещё вчера были очкали... (meeldib.ee). 
Новая визуальная жизнь шуточных вопросов в интернет-мемах 413

\section{Заключение}

Шуточные вопросы как жанр очень жизнеспособны, и диалоги в них происходят на разных уровнях. Вербально-визуальные аспекты загадок важны с точки зрения динамики и развития жанра, но не менее важны диалоги различных социокультурных контекстов, эпох, нового и старого и т. д.

Визуализация шуточных вопросов в виде мемов в социальных сетях может быть рассмотрена как динамический творческий процесс, в котором используются возможности визуальной коммуникации. Иногда изображение может выразить больше, чем тысяча слов, однако на основе данного анализа можно утверждать, что слова говорят больше и что одного лишь изображения недостаточно.

Вербальная и визуальная стороны тесно взаимодействуют друг с другом, но для понимания словесной части визуальная составляющая не дополняет значение. Процесс визуализации видится чем-то неотъемлемым, обязательной нормой, скорее, для онлайновой среды. В новейших медиа подобный глас народа представляет собой распространенный способ выражения альтернативных мнений и стереотипов.

Воздействие постмодернистских изображений в средствах массовой информации, влияние поп-культуры и потребительской культуры отчётливо чувствуется в шуточных вопросах. В то же время интересен тот факт, что люди помнят шутки советского периода и иллюстрируют их. А перед фольклористами стоит вопрос, как быть с таким визуально-текстовым фольклором, как его архивировать. Чтобы лучше понять и описать линии развития жанра загадок, эти сведения должны быть добавлены к уже существующим базам данных.

\section{Выражение благодарности}

Работа над статьёй осуществлена при поддержке Министерства образования и науки Эстонии (институциональный исследовательский грант IUT 22-5) и Фонда регионального развития EC (Центр компетенщии по Эстонским исследованиям CEES-TK 145). 


\section{Литература}

Attardo, Salvatore \& Raskin, Victor 1991. Script theory revis(it)ed: joke similarity and joke represenation model. HUMOR: International Journal of Humor Research 4-3/4, cc. 293-347.

Baran, Anneli 2013. On the Role of Visualisation in Understanding Phraseologisms on the Example of Commercials. Folklore: Electronic Journal of Folklore 53, cc. 47-72 (DOI: 10.7592/FEJF2013.53.baran).

Chiaro, Delia 1992. The Language of Jokes: Analysing Verbal Play. London, New York: Routledge.

Davies, Christie 1998. Jokes and their Relation to Society. Berlin and New York: Mouton de Gruyter.

Frank, Russell 2011. Newslore: Contemporary Folklore on the Internet. Jackson.

Krikmann, Arvo \& Krikmann, Jaak 2012. Eesti mõistatused. http://www. folklore.ee/moistatused/ (дата обращения 15.01.2018) (база данных, содержащая около 100000 загадок, послужила источником для составления академических изданий по эстонским загадкам (2001-2002)).

Laaniste, Mari 2005. Piltide ja kirja keelest. Keel ja Kirjandus 8, cc. 617-629.

Laineste, Liisi \& Voolaid, Piret 2016. Laughing across borders: Intertextuality of Internet memes. European Journal of Humour Research 4 (4), cc. 26-49 (DOI: 10.7592/EJHR2016.4.4.laineste (дата обращения 15.01.2018)).

Oring, Elliott 1992. Jokes and Their Relations. Lexington, Kentucky: The University Press of Kentucky.

Oring, Elliott 2003. Engaging Humor. Urbana and Chicago: University of Illinois Press.

Raskin, Victor 1985. Semantic Mechanisms of Humor: Synthese Language Library 24. Dordrecht, Boston, Lancaster: Reidel \& Hingham.

Shifman, Limor 2013. Memes in Digital Culture. Cambridge, London: MIT Press.

Stanoev, Stanoy 2010. Dumb Blondes and Democracy. Folklore: Electronic Journal of Folklore 46, cc. 43-60. http://www.folklore.ee/folklore/vol46/ stanoev.pdf (дата обращения 15.01.2018). 
Новая визуальная жизнь шуточных вопросов в интернет-мемах 415

Шмелева, Елена \& Шмелев, Алексей 2002. Русский анекдот: Текст и речевой жанр. Studia philologica. Series minor. Москва: Языки славянской культуры.

Virtanen, Leea 2000. Nelja uksega rosin. Koolinalju, hirmujutte, (pilt) mõistatusi, keerdküsimusi, rumalusteste, lollitamisi. Tallinn.

Voolaid, Piret 2002. Eesti piltmõistatused. http://www.folklore.ee/ Reebus/ (дата обращения 15.01.2018) (Около 8400 ребусов, версия на английском языке: Estonian Droodles - http://www.folklore.ee/ Droodles/).

Voolaid, Piret 2003. Eesti liitsõnamängud. http://www.folklore.ee/ Sonamang/ (дата обращения 15.01.2018) (база данных содержит около 5000 каламбуров).

Voolaid, Piret 2004a. Eesti keerdküsimused. http://www.folklore.ee/ Keerdkys/ (дата обращения 15.01.2018) (база данных содержит около 25000 шуточных вопросов).

Voolaid, Piret 2004b. Eesti lühendmõistatused. http://www.folklore.ee/ Lyhendid/ (дата обращения 15.01.2018) (база данных содержит около 3000 акронимов).

Wienker-Piepho, Sabine 1999. Kurjad keeled sugupooli käsitlevates naljades. Mäetagused 9. Tartu: Eesti Kirjandusmuuseum, cc. 133-145. http:// www.folklore.ee/tagused/nr9/blond.htm (дата обращения 15.01.2018).

\section{Summary}

\section{The new visual life of joking questions in Internet memes}

\section{Piret Voolaid}

Keywords: conundrums, humor, joking questions, memes, newslore, riddles

One of the most viable subgenres of riddles are humorous joking questions or conundrums. In their short, dialogic form, they are well suited for expressing vernacular views. They are very often born and disseminated as newslore, being a reaction to daily (political or other) events. The dynamics of the genre in social media shows a move towards illustrating and visualising. A characteristic feature of these multimodal and -medial memetic representations is their literary, digital, folk visual quality. 


\section{ПиРЕт ВоОЛАЙД}

In the presentation, I seek answers to the following questions:

- Which conundrums are illustrated and how?

- How often does inspiration come from the pre-digital period and in what way?

- What does visualisation add to the traditionally verbal joking questions in aesthetic and emotional sense (is the image merely an illustration to the text or do the verbal and the visual constitute a new whole?) These topics are often reflected upon through joking questions.

1. Conundrums as reactions to real life (eg political) events; newslore, with real politicians as characters.

2. Conundrums about the relationships of women and men, incl gender stereotypes.

3. Other daily topics, eg alcohol and drinking, IT and technology, consumer culture.

The impact of post-modernist images of mass media, popular and consumer culture is clearly visible in joking questions, at the same time it is interesting that people remember jokes from the Soviet period and illustrate them. Folklorists now face the question how to deal with such visual-textual folklore, how to archive it. To better understand and describe the developments in riddle genre, this data needs to be added to the existing database.

The material for the presentation is collected from the Estonian popular humour site meeldib.ee. This is open for all registered users who can post jokes, photos, videos, which have to be "their own intellectual creation". For a folklorist, this is anonymous folklore where the different layers of authorship are impossible to differentiate.

The material is viewed to the backdrop of the database "Estonian conundrums" (ca 25000 texts; www.folklore.ee/Keerdkys, Voolaid 2004). 


\section{МИССИЯ ВЫПОЛНИМА Перспективы изучения фольклора}

http://www.folklore.ee/rl/pubte/ee/sator/sator19/

ISSN 1736-0323

ISBN 978-9949-586-60-8

DOI: $10.7592 /$ Sator.2018.19

Тарту 2018

Редакторы-составители выпуска:

Маре Кыйва \& Татьяна Володина

Редактор серии: Маре Кыйва

Фото: Яак Кикас, 2018 «Осень в Тарту»

Оформление обложки: Лииса Весик

Верстка \& HTML: Диана Кахре

Печатное издание: МИССИЯ ВЫПОЛНИМА:

Перспективы изучения фольклора. SATOR 19. Тарту 2018

Публикация книги осуществлена совместно Эстонским литературным музеем и Центром исследований белорусской культуры, языка и лит ерат уры Националь ной акад емии наук Б еларус и, п ри поддержке Министерства образования и науки Эстонии (IUT 22-5), Фонда регионального развития ЕС (ТK 145, Центр компетенции по Эстонским исследованиям); при поддержке проекта, финансируемого Министерством иностранных дел Эстонии из бюджета по сотрудничеству и развитию, Эстонской Академией Наук и Национальной академии наук Беларуси.

Оформление электронного издания осуществлено при поддержке проекта ЕККМ14-344 “Расширение областей применения и представление эстонского языка, культуры и фольклора в электронных информационных средствах".

() Эстонский литературный музей

(c) Авторы

(с) Яак Кикас 